\title{
PENGEMBANGAN KETERPADUAN BINA KELUARGA REMAJA DAN PUSAT INFORMASI KONSELING REMAJA DI WILAYAH PERDESAAN DAN PERKOTAAN DAERAH ISTIMEWA YOGYAKARTA
}

\author{
Oleh: \\ Nurul Khotimah', Anik Ghufron, Kanthi Aryekti², Sri Sugiharti² \\ ${ }^{1}$ LPPM Universitas Negeri Yogyakarta \\ ${ }^{2}$ BKKBN Provinsi Daerah Istimewa Yogyakarta \\ nurulkhotimah@uny.ac.id
}

\begin{abstract}
Abstrak
Penelitian ini bertujuan mengidentifikasi dan menganalisis (1) layanan BKR dan PIK $R$, (2) faktor-faktor yang mempengaruhi remaja dalam pemanfaatan layanan PIK $R,(3)$ kegiatan sosial kemasyarakatan remaja, (4) sinergisitas BKR dan PIK R, serta menyusun (5) model pengembangan keterpaduan BKR dan PIK $R$, dan (6) modul pengembangan keterpaduan BKR dan PIK R. Penelitian ini menggunakan desain penelitian dan pengembangan (R\&D). Wilayah perdesaan dan perkotaan di DIY yang dijadikan sebagai lokasi penelitian ditentukan secara purposive yaitu BKR "Lentera Biru" dan PIK R "Paku Biru" untuk wilayah perdesaan dan BKR "Sekar Melati" dan PIK R "Tunas Kencana" untuk wilayah perkotaan. Hasil penelitian: (1) Wilayah perdesaan, layanan BKR berupa pertemuan penyuluhan, kunjungan rumah, pemantauan permasalahan remaja; sedangkan layanan PIK $\mathrm{R}$ berupa pertemuan penyuluhan. Wilayah perkotaan layanan BKR berupa pertemuan penyuluhan, kunjungan rumah, rujukan, pemantauan permasalahan remaja, layanan PIK R berupa pertemuan penyuluhan, (2) terdapat faktor internal dan eksternal yang berpengaruh dalam pemanfaatan layanan PIK R. (3) Kegiatan sosial kemasyarakatan remaja: olahraga, kesenian, keagamaan, karang taruna. (4) Sinergisitas BKR dan PIK R belum optimal. (5) Hasil Model Pengembangan Keterpaduan berupa Pelayanan terpadu, Integrasi layanan dengan kegiatan sosial kemasyarakatan, Penjadwalan pertemuan, Penambahan dan pengembangan materi. (6) Modul pengembangan keterpaduan diupayakan dengan membuat buku saku.
\end{abstract}

Kata kunci: Pengembangan, Keterpaduan, BKR, PIK R

\begin{abstract}
This research aims at identifying and analyzing (1) BKR and PIK R service; (2) factors affecting youth in utilizing PIK R service; (3) youth social activities; (4) synergy of BKR and PIK R; and desinging (5) a model of developing integrated BKR and PIK R, and (6) a modul of integrating BKR and PIK R. This research uses a research and development design. The rural and urban areas of DIY Province that serve as research setting are determined using purposive sampling technhiques consisting of BKR "Lentera Biru" and PIK R "Tunas Kencana" for rural areas and BKR "Sekar Melati" and PIK R "Tunas Kencana" for urban areas. The findings show that: (1) BKR services in rural areas include counseling meetings, home visits, and adolescent issues monitoring; while PIK R services are counselling meetings. Moreover, BKR services in urban areas consist of counseling meetings, home visits, referrals, youth issues monitoring, while PIK $R$ services are counseling meetings. (2) There are internal and external factors that influence the utilization of PIK R services. (3) Youth social activities include sports, arts, religious programs, youth organizations. (4) The synergy of BKR and PIK R is not optimal yet. (5) The results regarding the Integrated Development Model are integrated services,
\end{abstract}


Pengembangan Keterpaduan Bina Keluarga Remaja dan Pusat Informasi Konseling Remaja di Wilayah Perdesaan dan Perkotaan Daerah Istimewa Yogyakarta

integration between services and social activities, meeting scheduling, materials addition and development. (6) The modul of integration development is a pocket book.

Keywords: Development, Integration, BKR, PIK R

\section{PENDAHULUAN}

Masa remaja adalah masa peralihan dari anak-anak menuju masa dewasa. Masa remaja seringkali dihubungkan dengan beberapa permasalahan yang menyangkut kehidupan remaja, seperti permasalahan fisik (pubertas), permasalahan moral, permasalahan TRIAD KRR (seksualitas, HIV/AIDS, napza), rendahnya pengetahuan remaja tentang kesehatan reproduksi remaja, dan lain-lain.

Berdasarkan hasil survei Sumber Kesehatan Reproduksi Remaja Indonesia (SKKRI) pada tahun 2002-2003, diketahui bahwa remaja mempunyai teman yang pernah berhubungan seksual pada: (1) usia 14-19 tahun, yaitu perempuan sebesar $34,7 \%$, dan laki-laki sebesar 30,9\%, (2) usia 20-24 tahun, yaitu perempuan sebesar $48,6 \%$ dan laki-laki sebesar 46,5\% (Santrinawati, 2006). Depsos RI (2008) menyebutkan bahwa remaja yang beberapa generasi lalu masih malu-malu kini sudah melakukan hubungan seks di usia dini, yaitu usia 13-15 tahun. Muhammad Azinar (2013) juga menyebutkan bahwa sebesar $12,1 \%$ mahasiswa memiliki perilaku seksual berisiko terjadi kehamilan tidak diinginkan (KTD). Faktor-faktor yang secara signifikan mempengaruhi perilaku seksual pranikah pada mahasiswa adalah religiusitas, sikap terhadap seksualitas, akses dan kontak dengan media informasi, sikap teman dekat, dan perilaku seksual pranikah teman dekat.

Pusat Data dan Informasi, Kemenkes RI (2014b) menyebutkan bahwa permasalahan HIV dalam kurun waktu 2010-2014 didominasi kelompok usia produktif, yaitu usia 25-49 tahun, dan diikuti kelompok usia 20-24 tahun. Pola penularan HIV lebih banyak terjadi pada kelompok laki-laki daripada perempuan. Kejadian kasus AIDS di Indonesia dalam kurun waktu 1987-2014 didominasi kelompok usia 20-29 tahun, diikuti kelompok usia 3039 tahun, dan kelompok usia 40-49 tahun. Jika dikaitkan dengan karakteristik AIDS yang gejalanya baru muncul setelah 3-10 tahun terinfeksi, maka hal ini membuktikan bahwa mereka yang terkena AIDS telah terinfeksi sejak usia muda atau remaja. Kasus AIDS lebih banyak terjadi pada kelompok laki-laki (54\%) atau hampir 2 kali lipat jika dibandingkan pada kelompok perempuan (29\%). Angka kejadian kasus AIDS atau AIDS case rate yaitu jumlah kasus AIDS per 100.000 penduduk di suatu wilayah dalam kurun waktu tertentu, dalam hal ini di Indonesia kurun waktu 1987-2014 tertinggi di Provinsi Papua $(322,9)$, diikuti Papua Barat $(215,6)$, Bali $(100,2)$, DKI Jakarta $(59,7)$, Kalimantan Barat $(34,2)$, Sulawesi Utara (27,3), Maluku (24,2), D.I. Yogyakarta (21,1), Kepulauan Bangka Belitung $(19,3)$, dan Sumatera Barat $(18,8)$. AIDS case rate nasional sebesar 19,1 (Kemenkes RI, 2014b).

Dalam kurun waktu 2009-2012, jumlah pasien napza atau istilah yang populer dikenal masyarakat sebagai narkoba menurut Kemenkes RI (2014a) didominasi kelompok usia 30-34 tahun, namun pada tahun 2013 didominasi kelompok usia > 34 tahun. Jumlah pasien napza remaja atau kelompok usia 15-24 tahun, yaitu tahun 2009 sebesar 13,03\%, tahun 2010 sebesar 10,14\%, tahun 2011 sebesar 8,16\%, tahun 2012 sebesar 17,21\%, dan tahun 2013 sebesar 27,59\% (RSKO, 2014 dalam Kemenkes RI, 2014a).

Permasalahan remaja seperti diuraikan di atas, didukung besarnya arus globalisasi informasi yang tidak terkendali dan cenderung berdampak negatif bagi remaja sehingga mengakibatkan terjadinya perilaku hidup tidak sehat dan tidak berakhlak pada remaja 
Indonesia. Perilaku remaja ini akan mempengaruhi kualitas bangsa Indonesia dan program Generasi Berencana (GenRe) yang telah dicanangkan oleh BKKBN.

Berdasarkan hasil Sensus Penduduk tahun 2010, jumlah remaja atau penduduk usia 10-24 tahun di Daerah Istimewa Yogyakarta adalah sebesar 834.922 jiwa atau 28,3\% dari keseluruhan jumlah penduduk Daerah Istimewa Yogyakarta yang jumlahnya sebesar 2.950.721 jiwa. Jumlah remaja tersebut, terdiri dari 425.807 jiwa laki-laki $(51,0 \%)$ dan 409.115 jiwa perempuan (49,0\%) (BPS, 2010). Jumlah remaja yang cukup besar ini tentunya memerlukan perhatian dari berbagai pihak, baik pemerintah maupun masyarakat. Hal ini dikarenakan masa remaja adalah masa perubahan dari anak-anak menuju dewasa yang mempunyai masalah kompleks seiring masa transisi yang dialaminya.

Untuk melakukan respon terhadap permasalahan remaja, BKKBN telah melakukan suatu pendekatan yaitu pengembangan program GenRe. Program GenRe adalah suatu program yang dikembangkan dalam rangka penyiapan kehidupan berkeluarga bagi remaja yang diarahkan untuk mencapai tegar remaja agar menjadi tegar keluarga demi terwujudnya keluarga kecil, bahagia, dan sejahtera (BKKBN, 2014). Dasar hukum program Genre adalah Undang-Undang No. 52 tahun 2009, tentang Perkembangan Kependudukan dan Pembangunan Keluarga, Pasal 48 ayat 1 (b) yang menyebutkan: "Peningkatan kualitas remaja dengan pemberian akses informasi, pendidikan, konseling dan pelayanan tentang kehidupan berkeluarga".

Program GenRe diperlukan karena: (1) sebagai informasi yang berkaitan dengan penyiapan diri remaja menyongsong kehidupan berkeluarga yang lebih baik, (2) menyiapkan pribadi yang matang dalam membangun keluarga yang harmonis, dan (3) memantapkan perencanaan dalam menata kehidupan untuk keharmonisan keluarga. Program GenRe diarahkan untuk mewujudkan remaja berperilaku sehat dan bertanggung jawab serta terhindar dari resiko TRIAD KRR atau tiga resiko yang dihadapi remaja yang berkaitan dengan permasalahan seksualitas, napza, dan HIV/AIDS.

Pengembangan program GenRe dalam pelaksanaannya dilakukan melalui 2 (dua) pendekatan, yaitu pendekatan kepada keluarga melalui BKR dan pendekatan kepada remaja melalui PIK R. Pendekatan melalui kelompok BKR dilakukan agar keluarga (orangtua) mampu mendampingi anak remajanya berperilaku sehat dan bertanggung jawab. Orangtua berperan sebagai pendidik, panutan, konselor, komunikator, dan teman/sahabat remaja. Peran orangtua dalam BKR diharapkan mampu menekan pertumbuhan penduduk di Indonesia yang semakin lama semakin bertambah. Pendekatan melalui kelompok PIK R dilakukan untuk membantu remaja mencapai tugas pertumbuhan dan perkembangan pribadi (pertumbuhan fisik, mental, emosional, spiritual) dan membantu remaja mencapai tugas pertumbuhan dan perkembangan sosial (melanjutkan sekolah, mencari pekerjaan, memulai kehidupan berkeluarga, menjadi anggota masyarakat, mempraktekkan hidup sehat).

Berdasarkan analisis dan evaluasi hasil pencatatan \& pelaporan pelayanan kontrasepsi dan pengendalian lapangan, diketahui bahwa jumlah keluarga aktif pertemuan kelompok BKR bulan Mei tahun 2014 di semua Kabupaten/Kota di wilayah Daerah Istimewa Yogyakarta masuk dalam pencapaian kategori baik. Jumlah keluarga aktif pertemuan kelompok BKR dengan pencapaian kategori baik tertinggi adalah Kabupaten Bantul sebesar 99,66\%, diikuti Kabupaten Kulonprogo sebesar 96,72\%, Kabupaten Sleman sebesar 93,15\%, Kota Yogyakarta sebesar 93,13\%, dan terendah Kabupaten Gunungkidul sebesar 91,80\%. Jumlah keluarga aktif pertemuan kelompok BKR di Daerah Istimewa Yogyakarta masuk dalam kategori baik dengan pencapaian sebesar 
95,36\% (Perwakilan BKKBN DIY, 2014). Jumlah keluarga aktif pertemuan kelompok BKR masuk dalam kategori baik memungkinkan pengembangan BKR di Daerah Istimewa Yogyakarta lebih efektif dalam menanggulangi permasalahan remaja.

Jumlah PIK R/M Tegar bulan Mei tahun 2014 di Daerah Istimewa Yogyakarta dengan pencapaian tertinggi adalah Kota Yogyakarta yang masuk kategori cukup sebesar $80,0 \%$, diikuti Kabupaten Gunungkidul dengan pencapaian kategori cukup sebesar 75,0\%. Kabupaten Kulonprogo jumlah PIK R/M Tegar masuk kategori kurang dengan pencapaian sebesar $66,7 \%$, diikuti Kabupaten Bantul dan Sleman dengan pencapaian kategori kurang sebesar 64,29\%. Jumlah PIK R/M Tegar bulan Mei tahun 2014 di Daerah Istimewa Yogyakarta masuk dalam kategori kurang, dengan pencapaian sebesar $67,39 \%$. Hal ini menunjukkan bahwa tempat pelayanan konsultasi remaja jumlahnya masih terbatas di Daerah Istimewa Yogyakarta (Perwakilan BKKBN DIY, 2014).

Dari berbagai data diketahui bahwa kelompok BKR dan PIK $R$ memiliki peran penting untuk mengatasi permasalahan remaja di wilayahnya, namun demikian dalam pelaksanaan kegiatan juga mengalami berbagai kendala. Berdasarkan hasil penelitian Neneng Tripuspita dan Restu Syariefah Putri Ginanjar (2014) diketahui bahwa kendala yang dihadapi kader BKR dalam menanggulangi permasalahan remaja adalah pengaruh dari luar lingkungan desa yang membawa dampak negatif bagi remaja dan aspek pendanaan yang belum memadai untuk pembiayaan kegiatan kelompok BKR. Isa Al Awam H. Usman (2014) menyebutkan bahwa identifikasi awal terkait permasalahan yang dihadapi PIK Remaja, antara lain menemukan kurangnya jumlah pendidik sebaya dan konselor sebaya, keterbatasan pengetahuan akan cara mengelola PIK R, kurangnya pengalaman melakukan konseling, serta latar belakang budaya dan pendidikan yang berbeda dimana menimbulkan berbagai respon yang muncul dari lingkungan sosial.

Berdasarkan kendala yang dihadapi oleh BKR dan PIK R seperti di atas, maka perlu adanya penelitian tentang program kegiatan layanan BKR dan PIK $R$ untuk mengatasi permasalahan remaja. Kegiatan layanan BKR dan PIK $R$ selanjutnya dapat dianalisis untuk melihat keterpaduan keduanya dalam membina remaja di wilayah penelitian. Dari kegiatan layanan yang diberikan selanjutnya dapat dilihat faktor-faktor apa saja yang mempengaruhi remaja dalam pemanfaatan layanan PIK R. Faktor dimaksud dapat berupa faktor internal maupun faktor eksternal. Selain itu juga perlu diketahui kegiatan sosial kemasyarakatan apa saja yang telah dilakukan remaja dalam rangka menggali potensi dirinya serta bagaimana sinergisitas BKR dan PIK $R$ dalam pengelolaan layanan remaja. Dari analisis layanan BKR dan PIK $R$, faktor-faktor yang mempengaruhi remaja dalam pemanfaatan layanan PIK R, kegiatan sosial kemasyarakatan yang telah diupayakan remaja, dan sinergisitas antara BKR dan PIK R diharapkan dapat membantu peneliti dalam menyusun model dan modul pengembangan keterpaduan BKR dan PIK $R$ di wilayah perdesaan dan perkotaan Daerah Istimewa Yogyakarta.

\section{METODE}

Penelitian ini menggunakan desain penelitian dan pengembangan atau research and development (R\&D). Sasaran penelitian ini adalah 2 kelompok BKR dan 2 kelompok PIK R yang mewakili wilayah perdesaan dan perkotaan di Daerah Istimewa Yogyakarta. Wilayah perdesaan dan perkotaan di Daerah Istimewa Yogyakarta yang dijadikan sebagai lokasi penelitian ditentukan secara purposive. Pertimbangannya adalah wilayah yang menjadi juara dalam penilaian lomba BKR tahun 2015, sehingga untuk wilayah perdesaan diwakili keberadaan BKR "Lentera Biru" dan PIK R "Paku Biru" yang berada di Dusun Biru 
RW 30, Desa Trihanggo, Kecamatan Gamping, Kabupaten Sleman, sedangkan untuk wilayah perkotaan diwakili keberadaan BKR "Sekar Melati" dan PIK R "Tunas Kencana" yang berada di Badran RW XI, Kelurahan Bumijo, Kecamatan Jetis, Kota Yogyakarta. Adapun waktu penelitian ini adalah 8 (delapan) bulan, yaitu sejak bulan April sampai dengan bulan November 2015. Rancangan model pengembangan dalam penelitian ini adalah model prosedural yang bersifat deskriptif. Dalam penelitian ini, ada langkahlangkah atau tahapan pelaksanaan penelitian yang harus diikuti untuk menghasilkan produk. Pengumpulan data penelitian ini dilakukan dengan metode wawancara, observasi, dan dokumentasi. Langkah-langkah dalam penelitian ini mengacu pada langkah-langkah metode R\&D model Sugiyono, yang meliputi: (1) identifikasi potensi dan masalah, (2) pengumpulan data, (3) desain produk, (4) validasi desain, (5) revisi desain, (6) ujicoba produk, (7) revisi produk, (8) ujicoba pemakaian, (9) revisi produk, (10) produksi massal.

\section{HASIL DAN PEMBAHASAN}

\section{Profil BKR dan PIK R}

Untuk wilayah perdesaan penelitian ini dilakukan di BKR Lentera Biru dan PIK R Paku Biru. BKR Lentera Biru berada di Dusun Biru RW 30, Desa Trihanggo, Kecamatan Gamping Kabupaten Sleman. BKR Lentera Biru memiliki susunan pengurus BKR, meliputi: Pelindung, Pembina, Ketua, Sekretaris, Bendahara, dan Kader. BKR ini didirikan pada tahun 2013 berdasarkan Surat Keputusan Kepala Desa No. 04/KPTS.KD/TRH/2013 tanggal 11 Februari 2013. BKR Lentera Biru dengan ketuanya Ibu Wakijah, memiliki kader BKR sejumlah 4 orang dan anggota aktif kurang lebih 35 orang. BKR ini dibina, antara lain oleh: TP PKK, PLKB, Puskesmas Gamping II, SKPD KB, BKKBN, dan tokoh masyarakat.

Kegiatan BKR Lentera Biru setiap bulannya dilakukan pada hari Jumat minggu ketiga, pukul 16.00 WIB-selesai, dengan tempat kegiatan di rumah Ketua BKR. Mekanisme kegiatan BKR berupa penyuluhan dan simulasi. Penyuluhan yang diberikan, antara lain: tentang kesehatan reproduksi, HIV, AIDS, napza, pendidikan seks dini, kenakalan remaja, cara mendidik anak dan cara hidup sehat dengan berKB, pemantapan 8 fungsi keluarga, peran orangtua dalam pembinaan anak dan remaja, dan komunikasi efektif orangtua terhadap remaja. Waktu penyuluhan yang diberikan berkisar antara 1-2 jam. BKR saat ini telah memiliki sarana pendukung kegiatan seperti KIE kit, monopoli, dan buku administrasi. Untuk kelancaran kegiatan BKR sumber pendanaan diperoleh secara swadaya, serta bantuan dari kantor kelurahan, kecamatan, dan kantor KB.

Pada saat ini pelatihan yang telah diikuti kader BKR Lentera Biru adalah pelatihan dari Kantor KB (BKKBN DIY, Kabupaten Sleman). Materi pelatihan yang diperoleh meliputi: mekanisme pengelolaan BKR, pencatatan dan pelaporan $B K R$, bina suasana, 8 fungsi keluarga, pendewasaan usia perkawinan, kebijakan program genre, peran orangtua dalam pembinaan remaja, komunikasi efektif orangtua terhadap remaja, pencegahan dan penanganan kasus-kasus remaja, dan simulasi mendidik anak.

PIK R Paku Biru memiliki struktur kepengurusan sebagai berikut: Pembina, Ketua, Sekretaris, Bendahara, Pendidik Sebaya, dan Konselor Sebaya. Saat ini PIK R Paku Biru 
Pengembangan Keterpaduan Bina Keluarga Remaja dan Pusat Informasi Konseling Remaja di Wilayah Perdesaan dan

Perkotaan Daerah Istimewa Yogyakarta

memiliki jumlah Pendidik Sebaya sebanyak 4 orang dan jumlah Konselor Sebaya sebanyak 2 orang. Jumlah pengurus PIK R Paku Biru yang telah mengikuti kegiatan pelatihan dari BKKBN DIY sebanyak 2 orang (Ketua PIK R dan Pendidik Sebaya), dan saat ini memiliki jumlah anggota aktif kurang lebih 40 orang. Materi yang telah diterima pengurus PIK $R$ saat pelatihan, meliputi: pendewasaan usia perkawinan, 8 fungsi keluarga, life skills, free seks, HIV, AIDS, napza, dan kesehatan reproduksi. Tindak lanjut kegiatan pelatihan oleh pengurus PIK $\mathrm{R}$ adalah dengan memberikan informasi kepada anggota lainnya dalam pertemuan rutin bulanan.

Kegiatan PIK R Paku Biru dilakukan secara rutin, sebulan sekali setiap tanggal 10, pukul 19.30 WIB-selesai, dengan tempat bergilir di setiap anggota. Agenda pertemuan adalah membahas kegiatan PIK $R$, informasi dan diskusi, dan posyandu remaja. Pembinaan yang diperoleh PIK R Paku Biru adalah dari Ibu Ardini (PLKB Gamping) dan Ibu Eni (Puskesmas). Frekuensi pembinaan adalah 1 (satu) bulan sekali. Adapun materi yang diberikan saat pembinaan, meliputi: TRIAD KRR, kesehatan reproduksi, kesehatan mental, kesehatan rohani, asmara, life skills, dan sosial media.

Untuk wilayah perkotaan penelitian dilakukan di B Sekar Melati dan PIK R Tunas Kencana. BKR Sekar Melati berlokasi di Badran RW XI Kelurahan Bumijo Kecamatan Jetis Kota Yogyakarta. Susunan pengurus BKR Sekar Melati, terdiri dari: Penanggung Jawab, Ketua, Sekretaris, Bendahara, Sie Pendidikan, Sie Kesehatan (sesuai SK). BKR ini memiliki kader sejumlah 10 orang, anggota aktif kurang lebih 30 orang, dengan ketua Ibu Hazizah. Pembina kegiatan BKR meliputi: RT/RW, lurah, camat, TP PKK kelurahan, PLKB kelurahan, Kantor KB Kota/Provinsi, puskesmas, psikolog, dan kader BKR.

Kegiatan BKR Sekar Melati setiap bulannya dilakukan pada tanggal 5, pukul 16.00 WIB-selesai dan digabungkan dengan pertemuan apsari. Mekanisme kegiatan BKR Sekar Melati sama dengan BKR Lentera Biru, yaitu berupa: penyuluhan dan simulasi. Penyuluhan yang diberikan kepada anggota BKR, antara lain: tentang kesehatan reproduksi, HIV, AIDS, napza, pendidikan seks dini, kenakalan remaja, KB, dan komunikasi dalam keluarga. Adapun durasi waktu penyuluhan antara 1-2 jam. Untuk mendukung kegiatan penyuluhan, sarana yang dimiliki BKR Sekar Melati adalah KIE kit, monopoli, dan buku administrasi. Untuk mendukung kelancaran kegiatan, sumber pendanaan BKR berasal dari swadaya, bantuan kelurahan dan kecamatan, serta bantuan Kantor KB.

Kader BKR Sekar Melati telah mendapatkan pelatihan dari Kantor KB (BKKBN DIY) dan Kantor Kesehatan. Materi pelatihan yang telah diperoleh kader BKR dalam kegiatan pelatihan, antara lain: kesehatan reproduksi, HIV, AIDS, napza, pendidikan seks dini, kenakalan remaja, KB, dan komunikasi dalam keluarga.

PIK R Tunas Kencana memiliki struktur kepengurusan sebagai berikut: Ketua, Sekretaris, Bendahara, Divisi Kesehatan, Divisi Pendidikan, Divisi Minat Bakat, dan Divisi Jaringan Komunikasi. PIK R Tunas Kencana memiliki jumlah Pendidik Sebaya sebanyak 4 orang, jumlah Konselor Sebaya sebanyak 2 orang, dan jumlah anggota aktif kurang lebih 25 orang. Jumlah pengurus PIK R yang sudah mendapatkan pelatihan dari BKKBN DIY sebanyak 5 orang (Ketua, Divisi Jaringan Komunikasi, Divisi Pendidikan, dan Anggota). Materi yang diterima saat pelatihan, antara lain: TRIAD KRR, membuat poster masyarakat, 
dan outbond. Tindak lanjut dari kegiatan pelatihan adalah pemberian informasi ke teman lain dan sekaligus sebagai upaya evaluasi organisasi.

Kegiatan PIK R Tunas Kencana dilakukan secara rutin, yaitu pada minggu pertama tiap bulannya, pukul 19.30 WIB-selesai. Adapun tempat kegiatan adalah rotasi (berputar) di setiap anggota kelompok. Agenda pertemuan adalah membahas kegiatan PIK R, penyampaian materi dan diskusi. Pembinaan yang telah diperoleh PIK $R$ Tunas Kencana adalah pembinaan dari Ibu Rini (TP PKK kelurahan) dan Ibu Etin (PLKB kelurahan). Frekuensi pembinaan yang dilakukan oleh Pembina relatif jarang. Materi yang diberikan saat pembinaan adalah mengenai TRIAD KRR.

\section{Layanan BKR dan PIK R}

Layanan yang telah dilakukan oleh BKR Lentera Biru, antara lain: (1) BKR melakukan pertemuan penyuluhan, (2) BKR melakukan kunjungan rumah, dan (3) BKR melakukan pemantauan terhadap permasalahan remaja di wilayahnya. Layanan BKR tersebut masih terbatas, mengingat adanya beberapa kendala yang dihadapi BKR untuk melakukan kegiatan, antara lain: (1) kesibukan anggota sehingga tidak hadir dalam pertemuan rutin, (2) antusiasme warga dalam keikutsertaan BKR masih kurang, (3) pendanaan terbatas, dan (4) belum adanya alat peraga yang memadai. Harapan yang diinginkan oleh kelompok BKR Lentera Biru untuk kemajuan BKR ke depan adalah: (1) remaja ke depan lebih baik dalam pergaulan dan memiliki pola kehidupan yang baik, (2) BKR dapat mencakup seluruh wilayah Padukuhan Biru, (3) materi penyuluhan yang diberikan dapat diterapkan anggota BKR dalam kehidupan sehari-hari, (4) adanya narasumber dari luar untuk menambah pengetahuan pengurus dan anggota, (5) tersedianya alat peraga yang memadai, serta (6) adanya suntikan dana untuk kelancaran kegiatan.

Untuk mendukung program kerja BKR, maka upaya yang dilakukan kelompok BKR adalah menjalin upaya kerjasama dengan tokoh masyarakat, PLKB, dan puskesmas. Pengurus BKR juga selalu mendorong dan menyemangati anggotanya agar selalu mengikuti pertemuan rutin karena dengan hadir dalam pertemuan akan mendapat tambahan ilmu, menyemangati anggotanya untuk selalu membina dan mengawasi remaja di rumah, setiap bulan selalu mengusahakan adanya pertemuan rutin, dan berusaha mencarikan donatur kegiatan BKR. Pembina KB di wilayah Padukuhan Biru, khususnya Tim Penggerak PKK dan PLKB juga berusaha memotivasi keluarga yang mempunyai remaja untuk bergabung di BKR, memotivasi remaja untuk masuk di PIK R, membantu memecahkan permasalahan kelompok BKR, melakukan fasilitasi pelatihan kader, pendampingan kelompok BKR, serta mengembangkan kegiatan keterpaduan antara BKR dengan PIK $R$ dan posyandu remaja.

Layanan kelompok PIK R Paku Biru adalah pertemuan penyuluhan. Dalam kegiatan penyuluhan ada beberapa permasalahan yang pernah ditangani, permasalahan terselesaikan, dan permasalahan didiskusikan. Permasalahan yang pernah ditangani, yaitu: permasalahan asmara dan kesehatan reproduksi. Permasalahan terselesaikan, yaitu: permasalahan asmara dan kesehatan reproduksi, sedangkan permasalahan didiskusikan, yaitu: perbedaan pendapat antar anggota dan hubungan asmara dari anggota. Dari beberapa permasalahan yang dihadapi anggota kelompok PIK R Paku Biru belum ada permasalahan yang dirujuk karena sudah dapat diselesaikan oleh kelompok.

Hambatan yang dihadapi kelompok PIK R Paku Biru sehingga dapat mengganggu kelancaran kegiatan meliputi permasalahan yang dihadapi pihak pengurus, pihak 
pendidik sebaya, pihak konselor sebaya, dan pihak anggota. Permasalahan yang dihadapi pihak pengurus adalah kesulitan untuk melakukan pertemuan karena kesibukan anggota (sekolah, kerja), kekurangan dana, dan kekurangan fasilitas (buku, media, permainan yang berhubungan dengan kegiatan PIK R). Permasalahan dari pihak pendidik sebaya adalah perhatian sasaran (remaja) sewaktu diskusi masih kurang. Permasalahan dari pihak konselor sebaya adalah konseli masih malu-malu untuk menyampaikan masalah kepada konselor. Permasalahan dari pihak anggota adalah penyampaian materi dari narasumber kurang menarik (kurang inovasi) dan kurangnya media yang dimiliki kelompok PIK R. Kelompok PIK R Paku Biru mengemukakan tidak menemui hambatan dari Pihak Pembina. Upaya penyelesaian yang telah dilakukan oleh kelompok PIK R Paku Biru untuk mengatasi beberapa hambatan yang dialami adalah: (1) menyampaikan materi dengan lebih inovatif dan selalu diupdate, dan (2) pengurus membuat kegiatan yang lebih menarik bagi anggotanya.

Layanan yang telah diberikan BKR Sekar Melati terhadap anggotanya adalah: (1) BKR melakukan pertemuan penyuluhan, (2) BKR melakukan kunjungan rumah, (3) BKR melakukan rujukan ke mitra kerja, yaitu PKBI dan puskesmas, dan (4) BKR melakukan pemantauan terhadap permasalahan remaja di wilayahnya. Saat ini kendala yang dihadapi BKR untuk melakukan kegiatan adalah: (1) waktu, (2) sarana prasarana dan pendanaan terbatas, (3) variasi kegiatan kurang, (4) kehadiran anggota BKR pada setiap kegiatan belum sesuai yang diharapkan karena belum semua orangtua yang punya anak remaja mau bergabung di BKR, dan (5) penyuluhan belum efektif. Harapan dari kelompok BKR untuk kemajuan BKR ke depan adalah: (1) adanya pembinaan dan pelatihan rutin bagi kader BKR, (2) anggota BKR lebih aktif dalam bertanya dan sharing dengan kader untuk kemajuan anak dan remaja, (3) remaja di wilayah lebih maju, (4) remaja terbebas dari narkoba, (5) remaja memiliki kegiatan positif, (6) remaja tidak terpengaruh pergaulan bebas, (7) BKR dapat melibatkan anggota masyarakat/keluarga yang punya remaja lebih banyak, (8) BKR memiliki sarana prasarana dan dana yang memadai, serta (9) kegiatan BKR lebih bervariasi sehingga menarik bagi anggota.

Program kerja dan upaya yang telah dilakukan kelompok BKR Sekar Melati agar kegiatan BKR dapat berjalan dengan baik, antara lain: pengurus mempunyai rencana kerja atau program kerja yang dapat menghidupkan kelompok BKR, yaitu rencana keterpaduan dengan PIK R setiap 3 bulan sekali, bermitra dengan PKBI Kota Yogyakarta, adanya upaya kerjasama antara BKR dengan dengan kegiatan apsari, kantor KB, dan kader kesehatan. Pengurus BKR juga berupaya mengirim kader untuk mengikuti pelatihan, dan jika kader telah selesai mengikuti pelatihan maka diadakan refreshing/penyegaran oleh kader yang bersangkutan, selain juga melaksanakan pembinaan atau penyuluhan secara intensif. Upaya yang telah dilakukan oleh Pembina BKR untuk memajukan kelompok BKR, dalam hal ini TP PKK Kelurahan melaksanakan pembinaan secara intensif, yaitu dengan mengadakan pelatihan dan mengupayakan pemenuhan sarana prasarana serta dana melalui APBD. Upaya yang telah dilakukan PLKB untuk memajukan kelompok BKR adalah membantu mencarikan narasumber kegiatan, membantu mencarikan pendanaan kegiatan ke kantor KB, kecamatan dan kelurahan (Musrenbang), mengikutsertakan kelompok BKR setiap ada kegiatan pelatihan, membantu meningkatkan pengetahuan kelompok melalui lomba-lomba, dan mencoba mengkoordinasikan/ memadukan kegiatan BKR dengan kantor kesehatan.

Layanan kelompok PIK R Tunas Kencana adalah pertemuan penyuluhan. Dalam kegiatan penyuluhan ada beberapa permasalahan yang pernah ditangani, permasalahan terselesaikan, dan permasalahan didiskusikan. Permasalahan yang pernah ditangani 
adalah maraknya kehamilan tidak diinginkan (KTD) dan pergaulan anak kecil. Permasalahan terselesaikan adalah maraknya KTD dan pergaulan anak kecil. Permasalahan didiskusikan adalah maraknya KTD dan pergaulan anak kecil. Dari beberapa permasalahan yang dihadapi anggota kelompok PIK $R$ Tunas Kencana belum ada permasalahan yang harus dirujuk.

Hambatan yang dijumpai kelompok PIK R Tunas Kencana dalam berorganisasi, meliputi permasalahan dari pihak pengurus, pihak pendidik sebaya, pihak konselor sebaya, dan pihak anggota. Permasalahan dari pihak pengurus adalah kesulitan mengkader teman-teman yang baru. Permasalahan dari pihak pendidik sebaya adalah kurangnya keterbukaan dari anggota. Permasalahan dari pihak konselor sebaya adalah kurangnya keterbukaan anggota. Permasalahan dari pihak anggota adalah kurangnya partisipasi aktif anggota. PIK R Tunas Kencana mengemukakan tidak menemui hambatan dari Pihak Pembina. Upaya penyelesaian yang dilakukan oleh kelompok PIK R Tunas Kencana untuk mengatasi berbagai hambatan di atas adalah: (1) dengan melakukan pertemuan rutin, dan (2) pemberian materi yang baru dan inovatif.

\section{Faktor-Faktor yang Mempengaruhi Remaja dalam Pemanfaatan Layanan PIK R}

Faktor-faktor yang mempengaruhi remaja dalam pemanfaatan layanan PIK R Paku Biru berdasarkan pengamatan di lapangan adalah faktor internal dan eksternal. Faktor internal, yaitu: (a) kendala waktu dan tempat, (b) kemudahan akses informasi, dan (c) status remaja. Faktor eksternal, yaitu: (a) adanya pergantian kepengurusan, dan (b) adanya permasalahan lingkungan.

Pemanfaatan layanan PIK $R$ Tunas Kencana oleh remaja belum optimal juga dipengaruhi oleh faktor internal dan eksternal. Dalam hal ini faktor internal dikarenakan: (a) kendala waktu dan tempat untuk pelaksanaan kegiatan, (b) kemudahan akses informasi, dan (c) status remaja. Pemanfaatan layanan PIK R Tunas Kencana oleh remaja belum optimal juga dikarenakan faktor eksternal sebagai berikut: (a) adanya pergantian kepengurusan, dan (b) adanya permasalahan lingkungan.

Faktor internal dalam pemanfaatan layanan PIK R Paku Biru maupun PIK R Tunas Kencana berupa kendala waktu dimungkinkan karena pelaksanaan kegiatan PIK R berbarengan kegiatan yang lain (sekolah, bekerja), sedangkan kendala tempat dimungkinkan karena kondisi ruang yang digunakan untuk kegiatan terbatas. Faktor internal berupa kemudahan remaja untuk mengakses informasi adalah melalui media cetak (surat kabar, majalah, tabloid, dan lain-lain), media elektronik (radio, TV, website, handphone, MUPEN, dan lain-lain), maupun media luar ruang (billboard, baliho, leaflet, booklet, poster, spanduk, dan lain-lain). Kemudahan remaja untuk mengakses informasi dimungkinkan berbeda satu sama lain. Status remaja dalam hal ini adalah sekolah, tidak sekolah, dan sudah bekerja, mengingat remaja yang menjadi anggota PIK R adalah usia 10-24 tahun dan belum menikah.

Faktor eksternal dalam pemanfaatan layanan PIK R Paku Biru maupun PIK R Tunas Kencana berupa pergantian kepengurusan dimungkinkan karena ada pengurus PIK $R$ yang berkuliah atau bekerja di luar kota sehingga diperlukan adanya regenerasi kepengurusan. Adapun faktor eksternal berupa permasalahan lingkungan adalah permasalahan lingkungan keluarga, sekolah, dan masyarakat. Permasalahan keluarga, 
Pengembangan Keterpaduan Bina Keluarga Remaja dan Pusat Informasi Konseling Remaja di Wilayah Perdesaan dan

Perkotaan Daerah Istimewa Yogyakarta

seperti kasus perselingkuhan orangtua, perceraian orangtua, tidak adanya komunikasi yang baik antara orangtua dan anak, bahkan perselisihan antar anggota keluarga dapat memicu anak untuk enggan mengikuti kegiatan PIK R karena anak dimungkinkan merasa malu. Permasalahan lingkungan sekolah dapat terjadi karena pergaulan teman sebaya yang kurang baik. Permasalahan lingkungan masyarakat dapat terjadi karena faktor kerawanan masyarakat, seperti adanya peredaran minuman keras, anak putus sekolah/DO, pengangguran, dan lain-lain.

\section{Kegiatan Sosial Kemasyarakatan Remaja}

Kegiatan sosial kemasyarakatan yang diikuti remaja anggota PIK R Paku Biru beragam. Remaja ikut aktif dalam beberapa kegiatan sosial kemasyarakatan, antara lain: kegiatan olahraga, kegiatan kesenian, kegiatan keagamaan, dan kegiatan karang taruna.

Kegiatan sosial kemasyarakatan yang diikuti remaja anggota PIK R Tunas Kencana sama dengan remaja anggota PIK R Paku Biru. Dalam hal ini remaja aktif dalam mengikuti kegiatan olahraga, kegiatan kesenian (band, tari), kegiatan keagamaan (remaja masjid), dan kegiatan karang taruna.

Untuk meningkatkan pelayanan pengembangan remaja di daerah penelitian, maka perlu mengintegrasikan kegiatan layanan PIK $R$ dengan kegiatan pada anak remaja yang tergabung dalam kegiatan olahraga/kesenian tertentu, remaja masjid, karang taruna, sehingga selain remaja mengikuti kegiatan positif yang bermanfaat, mereka juga dapat berdiskusi untuk terhindar dari perilaku menyimpang, seperti seks bebas, penyalahgunaan narkoba, pernikahan dini, dan lain-lain. Pelayanan pengembangan remaja selanjutnya dioptimalkan dengan peningkatan sinergisitas kelompok BKR dan PIK R.

\section{Sinergitas BKR dan PIK R}

Berdasarkan pengamatan di lapangan diketahui bahwa sinergisitas antara BKR Lentera Biru dengan PIK R Paku Biru belum optimal. Dalam hal ini antara remaja dan orangtua mendapatkan informasi secara terpisah. Remaja mendapatkan informasi dari kelompok PIK R, sedangkan orangtua mendapatkan informasi dari kelompok BKR. Meskipun pada saat ini remaja lebih mudah mengakses informasi, namun masih ada sebagian orangtua yang memiliki pola pikir lama yaitu menabukan informasi kesehatan reproduksi kepada anaknya, sehingga informasi yang diperoleh orangtua dari kelompok BKR tidak disampaikan ke anaknya. Oleh sebab itu diperlukan adanya peningkatan sinergisitas antara BKR Lentera Biru dengan PIK R Paku Biru.

Sama halnya dengan BKR Lentera Biru dengan PIK R Paku Biru, maka sinergisitas BKR Sekar Melati dengan PIK R Tunas Kencana juga belum optimal. Remaja dan orangtua masih mendapatkan informasi secara terpisah, oleh sebab itu peningkatan sinergisitas BKR Sekar Melati dengan PIK R Tunas Kencana diperlukan agar informasi yang diterima remaja dan orangtua di daerah penelitian dapat selaras dan berkesinambungan.

Sinergisitas antara BKR dengan PIK R diperlukan untuk mengatasi kompleksnya permasalahan remaja saat ini. Sinergi harus dibangun antara BKR dan PIK $R$ karena ke depan BKR dan PIK $R$ tidak akan berjalan sendiri-sendiri, melainkan keduanya harus 
terintegrasi. Dengan adanya integrasi program antara BKR dan PIK $R$, maka keluarga yang mempunyai anak remaja dan remaja akan diajak bergabung dalam kelompok BKR. Keluarga yang telah aktif menjadi anggota BKR selanjutnya akan memotivasi kepada keluarga lain untuk ikut serta dalam kelompok BKR dan sekaligus memotivasi anaknya untuk ikut serta dalam kelompok PIK R. Integrasi antara BKR dan PIK R dilakukan dalam rangka program pembinaan remaja secara holistik dan terintegrasi dengan pembinaan keluarga.

\section{Model Pengembangan Keterpaduan BKR dan PIK R}

Model pengembangan keterpaduan BKR dan PIK $R$ dirancang berdasarkan hasil identifikasi dan analisis layanan BKR dan PIK $R$, faktor-faktor yang mempengaruhi remaja dalam pemanfaatan layanan PIK $R$, kegiatan sosial kemasyarakatan remaja, dan sinergisitas BKR dan PIK R di kedua daerah penelitian. Berdasarkan hasil identifikasi dan analisis diketahui bahwa kondisi awal: (1) layanan BKR di kedua daerah penelitian sudah baik, tetapi belum optimal dalam pertemuan dan materi yang diberikan, (2) layanan PIK $R$ di kedua daerah penelitian belum nampak aktif (PIK R dalam tahap tumbuh), dan (3) sinergisitas antara BKR dengan PIK R belum optimal.

Layanan BKR di kedua daerah penelitian sudah baik, tetapi belum optimal dalam pertemuan dan materi yang diberikan yang dimaksud adalah pada waktu pertemuan penyuluhan, narasumber/kader BKR telah menyampaikan materi dengan suara lantang, namun karena materi yang disampaikan cukup banyak dan dalam waktu yang singkat, sementara anggota BKR belum memperoleh materi dalam bentuk hardcopy maka dimungkinkan anggota BKR kurang jelas. Komunikasi yang dibangun masih bersifat satu arah, dalam hal ini narasumber menjelaskan dan anggota BKR mendengarkan penjelasan narasumber.

Layanan PIK R di kedua daerah penelitian belum nampak aktif (PIK R dalam tahap tumbuh), yang dimaksud adalah kegiatan pertemuan penyuluhan PIK $R$ yang dirancang bulanan belum dapat berjalan secara rutin. Salah satu faktor yang memegang peranan penting untuk tidak berjalannya kegiatan PIK $\mathrm{R}$ secara rutin adalah status remaja, baik yang masih sekolah maupun sudah bekerja. Kegiatan pertemuan penyuluhan sering diundur atau ditunda karena bersamaan waktunya dengan ujian tengah semester atau ujian akhir semester sekolah, dan lain-lain.

Sinergisitas antara BKR dengan PIK R di kedua daerah penelitian belum optimal yang dimaksud adalah antara orangtua dan remaja masih mendapatkan informasi secara terpisah. Kegiatan BKR baru diikuti orangtua remaja, sehingga dimungkinkan informasi kesehatan reproduksi yang diterima orangtua tidak disampaikan ke anaknya karena dianggap tabu. Ke depan sinergisitas BKR dengan PIK $\mathrm{R}$ dapat ditingkatkan dengan mengajak keluarga yang memiliki anak remaja dan remaja untuk bergabung dalam kegiatan $B K R$, sehingga komunikasi antara BKR dan PIK $R$ dapat terbangun dengan baik.

Dari identifikasi dan analisis kondisi awal BKR dan PIK $R$ di kedua daerah penelitian selanjutnya dilakukan intervensi. Pelaksanaan intervensi pertama dilakukan dengan penguatan kelompok BKR dan PIK R melalui penawaran program yaitu pelatihan bagi 
Pengembangan Keterpaduan Bina Keluarga Remaja dan Pusat Informasi Konseling Remaja di Wilayah Perdesaan dan

Perkotaan Daerah Istimewa Yogyakarta

kader BKR maupun pengurus PIK R di kedua daerah penelitian di kantor KB (BKKBN DIY). Kondisi yang diharapkan dengan adanya intervensi pertama adalah meningkatnya layanan BKR dan PIK R. Hasil intervensi pertama kemudian dilakukan monitoring dan evaluasi.

Dari hasil monitoring pertama diketahui bahwa dalam pertemuan penyuluhan diketahui adanya peningkatan layanan, komunikasi sudah dua arah meskipun dengan sarana prasarana terbatas. Komunikasi dua arah, dalam hal ini anggota tidak hanya mendengarkan penjelasan narasumber/pengurus, tetapi aktif dalam menanggapi hal-hal yang didiskusikan bersama, termasuk memberikan pertanyaan terhadap hal-hal yang baru didengar. Hasil monitoring pertama selanjutnya dievaluasi dengan pelaksanaan intervensi kedua, yaitu pelaksanaan model pengembangan.

Pelaksanaan intervensi kedua dirancang dengan Pelaksanaan Model Pengembangan Keterpaduan BKR dan PIK R sebagai berikut:

1. Adanya pelayanan terpadu antara BKR dan PIK $R$ dengan institusi/lembaga yang menangani remaja, baik program maupun kegiatan.

2. Adanya integrasi layanan BKR dan PIK $R$ dengan kegiatan sosial kemasyarakatan remaja.

3. Adanya penjadwalan pertemuan antara BKR dan PIK R yang dibuat secara bersamaan.

4. Adanya penambahan dan pengembangan materi BKR dan PIK R, termasuk penyusunan modul oleh peneliti.

5. Kondisi yang diharapkan dengan adanya intervensi kedua adalah peningkatan sinergisitas antara BKR dan PIK R. Hasil intervensi kedua kemudian dilakukan monitoring dan evaluasi.

Dari hasil monitoring kedua diketahui bahwa: (1) BKR dan PIK R di kedua daerah penelitian telah melakukan layanan terpadu dengan institusi/lembaga yang menangani remaja, seperti PKBI, puskesmas, dan kantor KB, (2) BKR dan PIK R di kedua daerah penelitian telah melakukan integrasi layanan BKR dan PIK $R$ dengan kegiatan sosial kemasyarakatan remaja, baik kegiatan olahraga, kesenian (tari, band), keagamaan (remaja masjid), maupun karang taruna, (3) BKR dan PIK R di kedua daerah penelitian telah berusaha membuat penjadwalan pertemuan antara BKR dan PIK $R$ secara bersamaan, namun kegiatan belum terlaksana, dan (4) BKR dan PIK R di kedua daerah penelitian telah berupaya melakukan penambahan dan pengembangan materi, yaitu dengan menggandakan materi pelatihan yang diterima oleh pengurus untuk dibagikan kepada anggota.

Hasil monitoring kedua kemudian dilakukan evaluasi. Dari pertemuan evaluasi akhir yang dihadiri oleh Kabid KS, SKPD KB, BPPM, Dinas Kesehatan, PLKB, BKR, dan PIK R, maka disepakati Hasil Model Pengembangan Keterpaduan BKR dan PIK R di wilayah perdesaan dan perkotaan sebagai berikut:

1. Adanya pelayanan terpadu antara BKR dan PIK $R$ dengan institusi/lembaga yang menangani remaja, baik program maupun kegiatan. 
2. Adanya integrasi layanan BKR dan PIK $R$ dengan kegiatan sosial kemasyarakatan remaja.

3. Adanya penjadwalan pertemuan antara BKR dan PIK R yang dibuat bersamaan (tiap 3 atau 6 bulan sekali).

4. Adanya penambahan dan pengembangan materi BKR dan PIK $R$, termasuk penyusunan modul pengembangan keterpaduan BKR dan PIK $R$.

\section{Modul Pengembangan Keterpaduan BKR dan PIK R}

Modul pengembangan keterpaduan BKR dan PIK R diupayakan dengan membuat buku saku "BKR dan PIK R" (terlampir). Modul yang didesain diharapkan dapat diaplikasikan untuk penguatan kelompok BKR dan PIK R di wilayah perdesaan dan perkotaan, selain melalui pelatihan Sumberdaya Manusia (SDM). Modul yang didesain selanjutnya divalidasi dengan menghadirkan beberapa pakar/ahli yang sudah berpengalaman untuk menilai produk yang dirancang dalam forum diskusi. Validasi desain dilakukan oleh Kabid KS, SKPD KB, BPPM, dan Dinas Kesehatan. Setelah mendapat masukan dari pakar/ahli, maka untuk meminimalisir kelemahan/kekurangan modul yang dibuat peneliti segera melakukan revisi desain. Desain yang sudah direvisi selanjutnya diujicoba di daerah penelitian dengan sampel terbatas. Jika masih dijumpai kelemahan/kekurangan dari modul maka dilakukan revisi kembali dan jika sudah dianggap layak maka modul dapat diproduksi secara massal.

\section{SIMPULAN}

Di wilayah perdesaan, layanan BKR Lentera Biru berupa: (1) pertemuan penyuluhan, (2) kunjungan rumah, dan (3) pemantauan terhadap permasalahan remaja di wilayah, sedangkan layanan PIK R Paku Biru berupa pertemuan penyuluhan. Di wilayah perkotaan, layanan BKR Sekar Melati berupa: (1) pertemuan penyuluhan, (2) kunjungan rumah, (3) rujukan, dan (4) pemantauan terhadap permasalahan remaja di wilayah, sedangkan layanan PIK R Tunas Kencana berupa pertemuan penyuluhan.

Faktor-faktor yang mempengaruhi remaja dalam pemanfaatan layanan PIK R di wilayah perdesaan sama dengan di wilayah perkotaan, yaitu dipengaruhi faktor internal dan eksternal. Faktor internal meliputi: (a) kendala waktu dan tempat, (b) kemudahan akses informasi (media cetak, media elektronik, media luar ruang), dan (c) status remaja (sekolah, tidak sekolah, bekerja), sedangkan faktor eksternal, meliputi: (a) pergantian kepengurusan, dan (b) permasalahan lingkungan (keluarga, sekolah, masyarakat). Kegiatan sosial kemasyarakatan remaja di wilayah perdesaan sama dengan di wilayah perkotaan. Remaja di kedua daerah penelitian aktif dalam mengikuti kegiatan olahraga, kegiatan kesenian (band, tari), kegiatan keagamaan (remaja masjid), dan kegiatan karang taruna. Sinergisitas antara BKR dan PIK R di wilayah perdesaan dan perkotaan belum optimal, dalam hal ini kegiatan layanan BKR dan PIK $R$ masih berjalan sendiri-sendiri. 
Pengembangan Keterpaduan Bina Keluarga Remaja dan Pusat Informasi Konseling Remaja di Wilayah Perdesaan dan

Perkotaan Daerah Istimewa Yogyakarta

Adanya integrasi program BKR dan PIK R dilakukan dalam rangka program pembinaan remaja secara holistik dan terintegrasi dengan pembinaan keluarga.

Dari pertemuan evaluasi akhir yang dihadiri oleh Kabid KS, SKPD KB, BPPM, Dinas Kesehatan, PLKB, BKR, dan PIK R, maka disepakati Hasil Model Pengembangan Keterpaduan BKR dan PIK $R$ di wilayah perdesaan dan perkotaan sebagai berikut: (a) Adanya pelayanan terpadu antara BKR dan PIK $R$ dengan institusi/lembaga yang menangani remaja, baik program maupun kegiatan. (b) Adanya integrasi layanan BKR dan PIK R dengan kegiatan sosial kemasyarakatan remaja. (c) Adanya penjadwalan pertemuan antara BKR dan PIK R yang dibuat bersamaan (tiap 3 atau 6 bulan sekali). (d) Adanya penambahan dan pengembangan materi BKR dan PIK $R$, termasuk penyusunan modul pengembangan keterpaduan BKR dan PIK R. (e) Modul pengembangan keterpaduan BKR dan PIK R diupayakan dengan membuat buku saku "BKR dan PIK R". Modul yang didesain diharapkan dapat diaplikasikan untuk penguatan kelompok BKR dan PIK R di wilayah perdesaan dan perkotaan. Modul yang didesain selanjutnya divalidasi oleh pakar/ahli (Kabid KS, SKPD KB, BPPM, Dinas Kesehatan). Setelah mendapat masukan dari pakar/ahli, maka untuk meminimalisir kelemahan/kekurangan modul, peneliti segera melakukan revisi desain. Desain yang sudah direvisi selanjutnya diujicoba di daerah penelitian dengan sampel terbatas. Jika masih dijumpai kelemahan/kekurangan maka dilakukan revisi kembali dan jika sudah dianggap layak maka modul dapat diproduksi secara massal.

\section{UCAPAN TERIMA KASIH}

Dalam kesempatan ini penulis mengucapkan terima kasih kepada LPPM UNY yang telah memberikan kesempatan bagi penulis untuk melakukan penelitian bekerjasama dengan BKKBN Provinsi Daerah Istimewa Yogyakarta.

\section{DAFTAR PUSTAKA}

BKKBN. (2014). Pedoman Pengelolaan Bina Keluarga Remaja. Jakarta: BKKBN Direktorat Bina Ketahanan Remaja.

BPS. (2010). Sensus Penduduk 2010. Yogyakarta: BPS DIY.

Depsos RI. (2008). Perilaku Seksual Remaja. Sabili. Nomor 14 Tahun XIV, 24 Januari 2008.

Isa Al Awam H. Usman. (2014). Peran Pendidik Sebaya dan Konselor Sebaya Pada Pusat Informasi dan Konseling Remaja di Kota Tidore Kepulauan, Propinsi Maluku Utara. Tesis. Yogyakarta: S2 Magister Studi Kebijakan UGM.

Kemenkes RI. (2014a). Buletin Jendela Data dan Informasi Kesehatan. Semester 1, 2014. ISSN 2088 - 270X.

Kemenkes RI. (2014b). Infodatin: Pusat Data dan Informasi Kementerian Kesehatan RI. Jakarta Selatan: Kementerian Kesehatan RI.

Muhammad Azinar. (2013). Perilaku Seksual Pranikah Berisiko Terhadap Kehamilan Tidak Diinginkan. KEMAS 8 (2), 2013, halaman 153-160. ISSN 1858-1196.

Neneng Tripuspita dan Restu Syariefah Putri Ginanjar. (2014). Peranan Kader Bina Keluarga Remaja Dalam Menanggulangi Kenakalan Remaja (Studi Deskriptif Pada Bina Keluarga Remaja Anggrek 11 di Desa Margahayu Selatan Kecamatan Margahayu Kabupaten Bandung). MORES: Jurnal Pendidikan Hukum, Pancasila, dan Kewarganegaraan. Vol. I, No.2 (Agustus 2014). Hal. 181-192. 
Perwakilan BKKBN DIY. (2014). Analisis \& Evaluasi Hasil Pelkon \& Dallap (Data Bulan Mei 2014). Yogyakarta: $B K K B N D I Y$.

Santrinawati. (2006). Hubungan Sikap Remaja terhadap Keperawanan dengan Hubungan Seksual Pranikah (Analisis Data SKKRI 2002-2003). Tesis. Yogyakarta: PSIKM, Pascasarjana, UGM.

Sugiyono. (2011). Metode Penelitian Kuantitatif Kualitatif dan R\&D. Bandung: Alfabeta. 